\title{
Expression of proteinase inhibitor-9/serpinB9 in non-small cell lung carcinoma cells and tissues
}

\author{
ILONA ROUSALOVA ${ }^{1}$, EVZEN KREPELA $^{1}$, JAN PROCHAZKA ${ }^{1}$, \\ JAN CERMAK $^{2}$ and KAMILA BENKOVA ${ }^{3}$ \\ ${ }^{1}$ Laboratories of Molecular and Cell Biology and ${ }^{2}$ Division of Surgery, Department of Pneumology and \\ Thoracic Surgery, ${ }^{3}$ Department of Pathology, University Hospital Bulovka, Prague, Czech Republic
}

Received July 22, 2009; Accepted September 9, 2009

DOI: 10.3892/ijo_00000498

\begin{abstract}
Human proteinase inhibitor-9 (PI-9)/serpinB9 is an intracellular ovalbumin-family serpin with nucleocytoplasmic distribution which is expressed in certain normal cell types and cancer cells of different origin. Due to binding and inactivating of granzyme B $(\mathrm{GrB})$, PI-9 can protect the cells from GrB-mediated apoptosis. High levels of PI-9 expression in certain cancer cells may contribute to their resistance against the immune mediated killing. So far, it is not known whether non-small cell lung cardinomas (NSCLCs) express PI-9 mRNA and a functional PI-9 protein. Herein we report for the first time that NSCLC cells express both PI-9 mRNA and protein and that there is a subset of NSCLC cells with upregulated PI-9 mRNA and protein expression. Futhermore, our work revealed that the PI-9 protein expressed in NSCLC cells can inhibit the active GrB. Finally, analysis of PI-9 mRNA expression in NSCLC tumours from surgically treated patients showed that the expression of this transcript is upregulated in the less-differentiated lung adenocarcinomas. We suggest, that the upregulated expression of PI-9 in NSCLC cells may serve to protect them from apoptosis induced by GrB.
\end{abstract}

\section{Introduction}

Lung cancer is the leading cause of cancer-related mortality around the world. Non-small cell lung cancer (NSCLC) accounts for most lung cancer cases. Surgical resection remains the single most consistent and successful option for cure. However, almost $70 \%$ of lung cancer patients present with locally advanced or metastatic disease at the time of diagnosis. Chemotherapy with concurrent radiotherapy is the

Correspondence to: Dr Evzen Krepela, Department of Pneumology and Thoracic Surgery, University Hospital Bulovka, Budinova 2, 18081 Prague 8, Czech Republic

E-mail: evzen.krepela@fnb.cz

Key words: non-small cell lung carcinoma, proteinase inhibitor-9, serpinB9, expression, granzyme B, caspase, apoptosis treatment of choice for some locally advanced lung cancers, and palliative chemotherapy for the metastatic disease. The introduction of anti-angiogenesis agents and tyrosine kinase inhibitors targeting the epidermal growth factor receptors has resulted in improved response rates for selected groups of NSCLC patients. Despite a large number of clinical trials testing various anticancer treatment strategies, the 5-year survival rate reaches only $15 \%$ (1).

Human proteinase inhibitor-9 (PI-9/SERPINB9) is a $42-\mathrm{kDa}$ serpin that is expressed in the cytoplasm and nuclei of certain normal cell types (2-4). PI-9 is a direct irreversible granzyme B $(\mathrm{GrB})$ inhibitor which reacts with $\mathrm{GrB}$ with a stoichiometry of inhibition of 1:1 and has a high second order association rate constant, indicating that it is a fast physiological inhibitor of GrB (3). Recent findings indicate that PI-9 can inhibit not only the GrB/perforin-mediated death pathway but also the FasL/Fas death pathway $(5,6)$. Both pathways lead to the activation of apoptotic executioner procaspase-3 and -7 , as well as initiate permeabilization of the outer mitochondrial membrane via cleavage of the $\mathrm{BH}-3$ only protein $\mathrm{Bid}$ and/or the Mcl-1 protein component of the Mcl-1•Bim complex (7-17). In addition, the secretory vesicles of human cytotoxic lymphocytes (CTLs) express also other granzymes (A, H, K and $\mathrm{M}$ ), which may deliver alternative death signals that operate independently of caspase activation and mitochondrial permeabilization $(18,19)$.

PI-9 is expressed abundantly in cells that express high levels of GrB, such as CTLs, i.e. natural killer (NK) cells and $\mathrm{CD}^{+} \mathrm{T}$ cells $(3,20,21)$. The main physiological function of PI-9 is to protect CTLs against the misdirected autonomous GrB during an immune response $(21,22)$. Besides protecting the CTLs, PI-9 may also defend bystander cells or antigenpresenting cells likely to be exposed to GrB during an immune response. The expression of PI-9 in B cells (3), monocytes (23), mast cells (24), endothelial and mesothelial cells (25), smooth muscle cells (26) and dendritic cells $(21,27)$ is consistent with such a role. Cells at immune-privileged sites including the eye lens capsula, testis, ovaries, placenta, embryonic stem cells also upregulate the PI-9 expression $(20,25,28)$.

The expression of PI-9 was variably detected in human malignant tumours including colon carcinoma (29) and nasopharyngeal carcinoma (30). In addition, certain cancer cell lines of breast, colon, cervix, and melanoma also showed 
different levels of PI-9 expression (29). So far, there is evidence that the upregulated expression of PI-9 in cancer cells may contribute to their resistance against the immune mediated killing and thus it may promote tumour growth and progression $(31,32)$.

To obtain clues on the role of PI-9 in lung cancer we investigated the expression status of PI-9 in NSCLC cell lines and in NSCLC tumours and matched lungs from surgically treated patients. Herein we report for the first time that PI-9 mRNA and protein are expressed at variable levels in NSCLC cells and tumours and that PI-9 protein from NSCLC cells can inhibit the active GrB.

\section{Materials and methods}

Cell lines. NSCLC cell lines used in the present study were obtained from the following sources: CALU-1, SKMES-1, A549, SKLU-1 and COR-L23 from the European Collection of Cell Cultures, Salisbury, UK; LXF-289, COLO-699 and LCLC-103H from the German Collection of Microorganisms and Cell Cultures, Braunschweig, Germany; NCI-H520 and NCI-H1299 from the American Type Culture Collection (ATCC), Rockville, MD, USA. The small cell lung carcinoma (SCLC) cell lines NCI-H69, NCI-H146, NCI-H209, NCIH345, NCI-H378, NCI-H82 and NCI-H446 were purchased from ATCC. Culture media and other suplements were from Sigma, St. Louis, MO, USA. The NSCLC cell lines were cultured in humidified atmosphere of air with $5 \% \mathrm{CO}_{2}$ at $37^{\circ} \mathrm{C}$ in the Eagle's minimum essential medium supplemented with $5 \%$ foetal bovine serum, $26.2 \mathrm{mM} \mathrm{NaHCO}, 2 \mathrm{mM} L$ glutamine, $1 \%$ of a stock solution of non-essential amino acids, $0.25 \mu \mathrm{M} \mathrm{Fe}\left(\mathrm{NO}_{3}\right)_{3}, 10 \mathrm{mg} / \mathrm{l}$ apotransferrin, and $10^{5} \mathrm{IU} / \mathrm{l}$ of penicillin-G and $100 \mathrm{mg} / \mathrm{l}$ of streptomycin. After reaching confluency, the cells were scraped into a lysis solution for the isolation of total RNA or into the $\mathrm{Ca}^{2+}$ - and $\mathrm{Mg}^{2+}$-free Hanks' balanced salt solution for protein extracts and cytosols preparation (see below). The SCLC cell lines were grown in humidified atmosphere of air with $5 \% \mathrm{CO}_{2}$ at $37^{\circ} \mathrm{C}$ in RPMI1640 medium supplemented with $10 \%$ foetal bovine serum, $23.8 \mathrm{mM} \mathrm{NaHCO}, 2 \mathrm{mM} \mathrm{L}$-glutamine, and $10^{5} \mathrm{IU} / 1$ of penicillin- $\mathrm{G}$ and $100 \mathrm{mg} / \mathrm{l}$ of streptomycin. The cells were harvested by centrifugation at $240 \mathrm{x}$ g and $4^{\circ} \mathrm{C}$ for $10 \mathrm{~min}$.

Patients and tissues. One hundred and fifty patients with NSCLC tumours were investigated in this study (median age, 62 years; age range, 39-78 years; 110 men and 40 women; 130 smokers and 20 non-smokers). The patients did not receive any chemotherapy or radiotherapy before surgery. The surgical treatment applied to the patients included lung lobectomy, bilobectomy or pneumonectomy, and regional lymph node dissection. The histopathological classification of lung tumours was carried out according to the World Health Organization criteria (33) and tumour staging was performed according to the international pTNM system (34). The following NSCLC types were examined in the present study: squamous cell lung carcinoma (SQCLC), lung adenocarcinoma (LAC), SQCLC + LAC mixed type tumours, large cell lung carcinoma (LCLC), sarcomatoid lung carcinoma (SLC) and undifferentiated lung carcinoma (UNDIF). Besides the NSCLC tumours we also examined two small cell lung carcinomas (SCLCs) from patients who did not receive chemotherapy or radiotherapy before surgery. Signed, written informed consent was obtained from each patient before entry to the study. The study was approved by the local institutional ethics committee.

Specimens of primary lung tumour and matched lung parenchyma (190-240 mg, wet mass) were excised immediately after surgery. Tumour samples were taken from a non-necrotic part of the tumour and lung samples were excised from lung parenchyma at a site located as distantly as possible from the tumour location. All tissue samples were snap-frozen in liquid nitrogen and were stored at $-78^{\circ} \mathrm{C}$ until isolation of RNA and protein extraction.

Isolation and quantification of total RNA. Total RNA was extracted from NSCLC cell lines and NSCLC and lung tissue samples with using the TriZol Reagent (Invitrogen, Paisley, UK) according to the manufacturer's instructions. All RNA samples had an $\mathrm{A}_{260 \mathrm{~nm}} / \mathrm{A}_{280 \mathrm{~nm}}$ ratio $>1.8$ by spectrophotometric analysis in $10 \mathrm{mM}$ Tris/ $\mathrm{HCl}$ buffer, $\mathrm{pH}$ 7.5. The concentration of total RNA was determined by fluorometry using the RiboGreen RNA quantitation kit (Molecular Probes, Eugene, OR, USA) and the manufacturer's protocol.

Real-time RT-PCR analysis. The sequences and final concentrations of the oligonucleotide primers and probes used in real-time RT-PCR assays of expression of the investigated transcripts are indicated in Table I. The primers and probes were designed with the program Primer Express (Applied Biosystems, Foster City, CA, USA) and were synthesized at Proligo (Paris, France) and Applied Biosystems (Weiterstadt, Germany), respectively. The expression of PI-9 and B-actin mRNAs (an internal reference transcript) was quantitated by a coupled real-time RT-PCR assay. The RT-PCR reaction mixtures of a total volume of $50 \mu \mathrm{l}$ contained $25 \mu \mathrm{l}$ of ThermoScript reaction mix (a buffer with $3 \mathrm{mM} \mathrm{MgSO}_{4}$ and $200 \mathrm{nM}$ of each dGTP, dCTP, dATP and dTTP) and $1 \mu \mathrm{l}$ of ThermoScript Plus reverse transcriptase/platinum Taq DNA polymerase mix (both Mixes were from Platinum Quantitative RT-PCR ThermoScript One-Step system, Invitrogen), the respective primers and TaqMan probe at the indicated final concentrations (Table I), 40 units of inhibitor RNaseOUT (Invitrogen), and $200 \mathrm{ng}$ of total RNA. The final concentrations of primers and TaqMan probes adopted for real-time RTPCR quantification of each indicated transcript were determined in optimisation experiments. The real-time RTPCR assays were run in triplicate or duplicate in MicroAmp Optical 96-well Reaction Plates on the ABI PRISM 7700 Sequence Detection System using Sequence Detection System software (all from Applied Biosystems). The reverse transcription was carried out at $58^{\circ} \mathrm{C}$ for $30 \mathrm{~min}$ and the subsequent PCR amplification included a hot start at $95^{\circ} \mathrm{C}$ for $5 \mathrm{~min}, 45$ cycles of denaturation at $95^{\circ} \mathrm{C}$ for $15 \mathrm{sec}$ and of annealing/ extension at $58^{\circ} \mathrm{C}$ for $1 \mathrm{~min}$. The threshold cycle $\left(\mathrm{C}_{\mathrm{T}}\right)$ values of the amplification reactions, represented by the plots of background-subtracted fluorescence intensity $(\Delta \mathrm{FU})$ of the reporter dye (6-FAM or VIC) against PCR cycle number, were determined with the Sequence Detection System software. The statistical difference of the $\beta$-actin mRNA-normalized target transcript expression in tumours and lungs was calculated 
Table I. Primers and TaqMan probes used for real-time RT-PCR quantitation of expression of the investigated transcripts.

\begin{tabular}{lcccc}
\hline & $\begin{array}{c}\text { GeneBank } \\
\text { Transcript } \\
\text { accession no. }\end{array}$ & & Sequences & $\begin{array}{c}\text { Final } \\
\text { concentration }\end{array}$ \\
\hline $\begin{array}{l}\text { Proteinase } \\
\text { inhibitor-9 }\end{array}$ & NM_004155 & Forward primer: & 5'-TGGACCAAGCCAGACTGTATG-3' & $400 \mathrm{nM}$ \\
& & Reverse primer: & 5'-TGCACGAACTTGGACAGACA-3' & $400 \mathrm{nM}$ \\
3-actin & NM_001101 & Forward primer: & 5'-CTGGCACCCAGCACAATG-3' & $200 \mathrm{nM}$ \\
& & Reverse primer: & 5'-GGGCCGGACTCGTCATAC-3' & $200 \mathrm{nM}$ \\
& & TaqMan probe: & 5'-(VIC)AGCCGCCGATCCACACGGAGT(TAMRA)-3' & $200 \mathrm{nM}$ \\
& & & & $200 \mathrm{nM}$ \\
\hline
\end{tabular}

from the linearized $\Delta \mathrm{C}_{\mathrm{T}}$ data (i.e. $2^{-\Delta \mathrm{C} \mathrm{T}}$ ) and the tumour/lung ratio of the $B$-actin mRNA-normalized target transcript expression was calculated by means of the $2^{-\Delta \Delta \mathrm{C}_{\mathrm{T}}}$ method (35).

Preparation of protein extracts and cytosols and total protein determination. NSCLC cell lines were scraped into the $\mathrm{Ca}^{2+}$ and $\mathrm{Mg}^{2+}$-free Hanks' balanced salt solution and sedimented by centrifugation at $240 \mathrm{x} \mathrm{g}$ and $4^{\circ} \mathrm{C}$ for $10 \mathrm{~min}$. The subsequent processing of cells was carried out at $0-4^{\circ} \mathrm{C}$ and the resultant extracts and cytosols were stored in small aliquots at $-78^{\circ} \mathrm{C}$ until analysis. For Western blot analysis of PI-9 expression, the cells were disrupted by sonication in a lysis buffer containing $0.5 \%$ Triton $\mathrm{X}-100,0.005 \%$ Tween-20, and a mixture of proteinase inhibitors, $1 \mathrm{mM} \mathrm{Na}{ }_{2}$ EDTA, $50 \mu \mathrm{M}$ E-64, $200 \mu \mathrm{M}$ AEBSF and $25 \mu \mathrm{M}$ pepstatin, in phosphatebuffered saline, $\mathrm{pH}$ 7.2-7.4. For the assay of procaspase-3/-7 activation by exogenous recombinant $\mathrm{GrB}$, the cell lysis buffer was $20 \mathrm{mM}$ HEPES/NaOH, pH 7.0, and contained $6 \mathrm{mM}$ Zwittergent ${ }^{3-12}$ Detergent, $10 \mathrm{mM} \mathrm{NaCl}$ and $1 \mathrm{mM} \mathrm{Na}_{2}$ EDTA. The cell homogenates were centrifuged at $40000 \mathrm{x} \mathrm{g}$ and $4^{\circ} \mathrm{C}$ for $30 \mathrm{~min}$. For preparation of cytosols, the cells were resuspended in 0.3-0.5 volumes of buffer $25 \mathrm{mM}$ HEPES/ $\mathrm{NaOH}, 4$ mM Na${ }_{2}$ EDTA, $1.5 \mathrm{mM} \mathrm{MgCl} 2,10 \mathrm{mM} \mathrm{KCl}$, pH 7.4, and were disrupted in a Dounce homogeniser using the pestle B. The homogenate was centrifuged at $200,000 \mathrm{x} \mathrm{g}$ and $4^{\circ} \mathrm{C}$ for $60 \mathrm{~min}$ and the supernatant was collected as cytosol. Total protein concentration was determined by the bicinchoninic acid assay with using bovine serum albumin (BSA) as a standard (36).

Western blot analysis. The expression of PI-9 in NSCLC cell lines was investigated by denaturing SDS-polyacrylamide gel electrophoresis (SDS-PAGE) and immunoblotting with specific antibodies. Cell extract samples were preboiled for

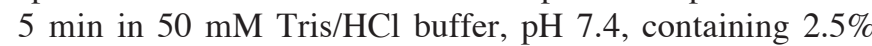
SDS, $100 \mathrm{mM}$ dithiothreitol, 5\% glycerol and $0.01 \%$ Serva Blue G. Then, $100 \mu \mathrm{g}$ protein samples were separated on 14\% $\mathrm{T} / 3 \% \mathrm{C}$ polyacrylamide gels using the Tris-Tricine-SDS buffer system (37). The Precision Plus Protein Prestained Standards (BioRad, Hercules, CA, USA) were run in parallel to the protein samples. The separated proteins were electrotransferred onto sheets of Hybond P membrane (Amersham Pharmacia Biotech, Little Chalfont, UK) using a transfer buffer $48 \mathrm{mM}$ Tris, $39 \mathrm{mM}$ glycine, $1.3 \mathrm{mM}$ SDS, and $20 \mathrm{v} / \mathrm{v} \%$ methanol, pH 9.2. PI-9 protein was visualised by an immunodetecting procedure coupled to an enhanced chemiluminiscence generating system. The primary antibody was

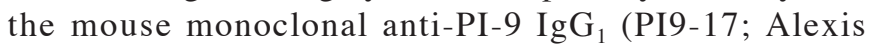
Biochemicals, Lausen, Switzerland; Cat. No. ALX-804-457) and the secondary antibody was the goat anti-mouse $\mathrm{IgG}_{1}$ HRP peroxidase conjugate (Sigma). The immunoblotting procedure was done at room temperature with the following steps: blocking with 5\% Blotting Grade Blocker (BGB; BioRad) and $1 \%$ bovine serum albumin (BSA) in PBST buffer (20 mM NaH${ }_{2} \mathrm{PO}_{4} / 80 \mathrm{mM} \mathrm{Na}_{2} \mathrm{HPO}_{4}, 100 \mathrm{mM} \mathrm{NaCl}$, and $0.1 \%$ Tween-20, $\mathrm{pH}$ 7.4) for $1 \mathrm{~h}$, incubation with the primary antibody (at $1 \mu \mathrm{g} / \mathrm{ml}$ in $1 \%$ BGB and $0.2 \%$ BSA in PBST buffer) for $2 \mathrm{~h}$, extensive washing with PBST buffer, incubation with the secondary HRP-conjugated antibody (at a dilution of $1: 10000$ in $1 \%$ BGB and $0.2 \%$ BSA in PBST buffer) for $1 \mathrm{~h}$, extensive washing with PBST buffer, incubation with the ECL Plus Reagent (Amersham Pharmacia Biotech) for $5 \mathrm{~min}$, and capture of the chemiluminescence signal on BioMax Light-1 film (Eastman Kodak, Rochester, NY, USA).

To find out whether PI-9 in the cytosol from NSCLC cells interacts with $\mathrm{GrB}$, we incubated cytosol samples from several NSCLC cell lines with human recombinant GrB (hrGrB; Calbiochem, Luzerne, Switzerland; Cat. No. B63047) for $15 \mathrm{~min}$ at $37^{\circ} \mathrm{C}$. The reactions contained $72 \mathrm{ng}$ of $\mathrm{hrGrB}$ per $100 \mu \mathrm{g}$ of total cytosolic protein and run in $11.25 \mathrm{mM}$ HEPES/NaOH buffer, pH 7.4, with $1.8 \mathrm{mM} \mathrm{Na}{ }_{2}$ EDTA, $13.7 \mathrm{mM} \mathrm{NaCl}, 4.8 \mathrm{mM} \mathrm{KCl}, 0.68 \mathrm{mM} \mathrm{MgCl}_{2}, 0.81 \mathrm{mM}$ $\mathrm{Na}_{2} \mathrm{HPO}_{4}$ and $0.15 \mathrm{mM} \mathrm{KH} \mathrm{PO}_{4}$. After denaturation and separation of proteins by SDS-PAGE and protein transfer onto the Hybond P membrane (see above), we probed for a simultaneous shift of hrGrB and PI-9 to higher $\mathrm{M}_{\mathrm{r}}$ values using a mouse monoclonal anti-GrB IgG $_{1}$ antibody (2C5; Santa Cruz Biotechnology, Santa Cruz, CA, USA; Cat. No. sc-8022) and the anti-PI-9 antibody PI9-17, respectively. The immunoblotting procedure was the same as described above. As a negative control, a mixture of hrGrB (35 ng) and BSA (4.8 $\mu \mathrm{g}$; Sigma, Cat. No. A-7030) was analysed in parallel.

Activation of procaspases by granzyme $B$. The endogenous and GrB-induced caspase-3-like activity in extracts from NSCLC cell lines was measured with $50 \mu \mathrm{M}$ Ac-DEVD-AFC (Bachem, Bubendorf, Switzerland) as a fluorogenic substrate in $50 \mathrm{mM}$ HEPES/NaOH buffer, $\mathrm{pH}$ 7.4, containing $10 \mathrm{mM}$ dithiothreitol, 
Table II. Real-time RT-PCR analysis of proteinase inhibitor-9 mRNA expression in non-small cell lung carcinoma and lung tissues.

\begin{tabular}{|c|c|c|c|c|c|c|}
\hline \multirow{2}{*}{$\begin{array}{l}\text { Tumor } \\
\text { type }\end{array}$} & \multirow[b]{2}{*}{$\mathrm{N}$} & \multicolumn{2}{|c|}{$\begin{array}{l}\text { ß-actin mRNA-normalised } \\
\text { expression of PI-9 mRNA }\left(2^{-\Delta \mathrm{C}_{\mathrm{T}}}\right)^{\mathrm{b}}\end{array}$} & \multirow{2}{*}{$\begin{array}{c}\text { Statistical difference }(\mathrm{P}) \\
\text { of PI-9 mRNA } \\
\text { expression in } \\
\text { Tu versus } \mathrm{Lu}^{\mathrm{c}}\end{array}$} & \multirow{2}{*}{$\begin{array}{l}\text { Tu/Lu ratio } \\
\text { of PI-9 mRNA } \\
\text { expression }\end{array}$} & \multirow{2}{*}{$\begin{array}{l}\text { No. of patients with } \\
\text { Tu/Lu PI-9 mRNA } \\
\text { expression ratio } \\
\geq 2 \text { and } \leq 0.5\end{array}$} \\
\hline & & Tumors (Tu) & Lungs (Lu) & & & \\
\hline NSCLC & $150^{\mathrm{a}}$ & $\begin{array}{c}0.0172 \\
(0.0002-0.3737)\end{array}$ & $\begin{array}{c}0.0173 \\
(0.0003-0.4506)\end{array}$ & 0.816 & $\begin{array}{c}0.9 \\
(0.09-23.3)\end{array}$ & $26(17 \%)$ and $28(19 \%)$ \\
\hline SQCLC & 69 & $\begin{array}{c}0.0172 \\
(0.0002-0.2132)\end{array}$ & $\begin{array}{c}0.0138 \\
(0.0003-0.4506)\end{array}$ & 0.811 & $\begin{array}{c}0.9 \\
(0.16-23.3)\end{array}$ & $13(19 \%)$ and $12(17 \%)$ \\
\hline LAC & 56 & $\begin{array}{c}0.0163 \\
(0.0008-0.3737)\end{array}$ & $\begin{array}{c}0.0294 \\
(0.0015-0.2774)\end{array}$ & 0.275 & $\begin{array}{c}0.8 \\
(0.09-5.3)\end{array}$ & $8(14 \%)$ and $16(29 \%)$ \\
\hline LCLC & 7 & $\begin{array}{c}0.0144 \\
(0.0078-0.0988)\end{array}$ & $\begin{array}{c}0.0082 \\
(0.0056-0.0960)\end{array}$ & 0.382 & $\begin{array}{c}1.8 \\
(0.95-2.6)\end{array}$ & $3(43 \%)$ and 0 \\
\hline SLC & 4 & $\begin{array}{c}0.0455 \\
(0.0150-0.0643)\end{array}$ & $\begin{array}{c}0.0499 \\
(0.0274-0.0587)\end{array}$ & 0.885 & $\begin{array}{c}1.1 \\
(0.35-1.2)\end{array}$ & 0 and $1(25 \%)$ \\
\hline UNDIF & 11 & $\begin{array}{c}0.0146 \\
(0.0024-0.1267)\end{array}$ & $\begin{array}{c}0.0067 \\
(0.0017-0.0802)\end{array}$ & 0.308 & $\begin{array}{c}1.5 \\
(0.53-4.6)\end{array}$ & $2(18 \%)$ and 0 \\
\hline
\end{tabular}

${ }^{\mathrm{a}} \mathrm{A}$ total of 150 NSCLC patients was studied including 69 pacients with SQCLC, 56 patients with LAC, 3 patients with SQCLC + LAC mixed type tumours, 7 patients with LCLC, 4 patients with SLC, and 11 patients with UNDIF. ${ }^{b}$ Data are indicated as median with the range in parentheses. 'Statistical difference of the B-actin mRNA-normalised PI-9 mRNA expression in Tu versus Lu was calculated by the MannWhitney test.

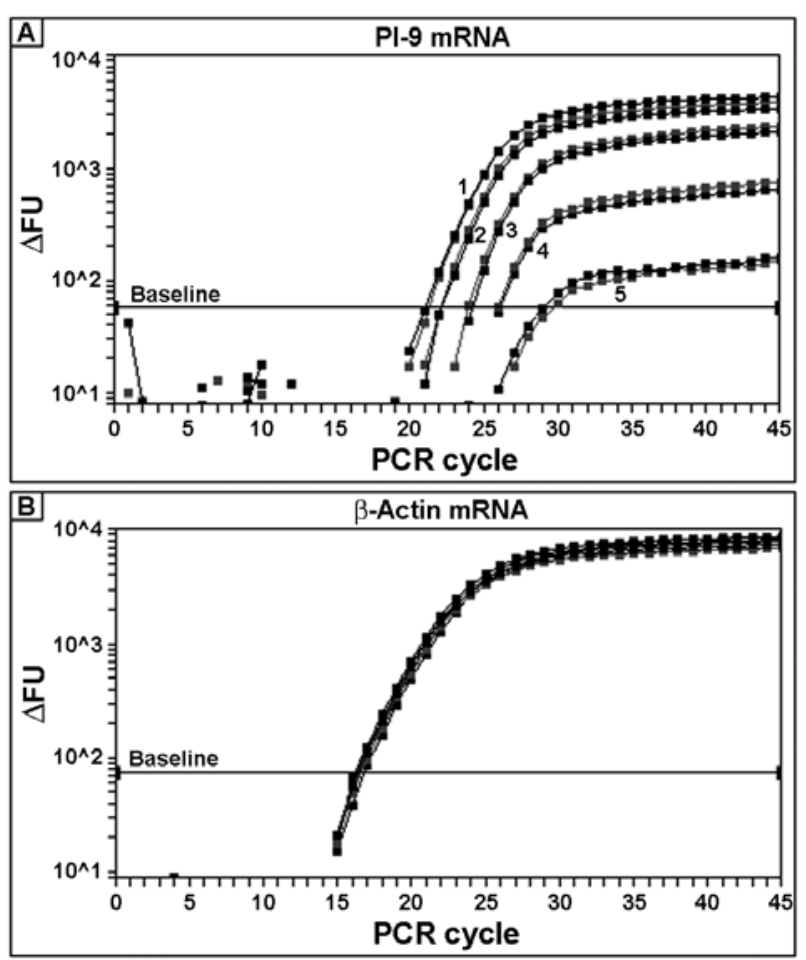

Figure 1. Real-time RT-PCR quantitation of expression of (A) PI-9 mRNA and (B) B-actin mRNA (an endogenous reference transcript) in NSCLC cell lines (1, LXF-289; 2, CALU-1; 3, NCI-H1299; 4, SKLU-1; 5, COLO-699). All real-time RT-PCR assays were performed with an input of $200 \mathrm{ng}$ of total RNA and were run in duplicate.
$1.63 \mathrm{mM}$ CHAPS, $1 \mathrm{mM} \mathrm{Na} \mathrm{EDTA}_{2}, 292 \mathrm{mM}$ sucrose and $100 \mathrm{mM} \mathrm{NaCl}$, with or without adding of $160 \mathrm{ng} / \mathrm{ml}$ of purified cell-derived human granzyme B (Calbiochem). Enzymatic reactions were started with the addition of $20 \mu 1$ of cell extract ( $25 \mu \mathrm{g}$ total protein) to $180 \mu \mathrm{l}$ of prewarmed buffersubstrate solution with or without GrB. Control reactions, which were done in parallel, run in the cell lysis buffer alone (i.e. a control for Ac-DEVD-AFC cleveage by GrB) or in the presence of the caspase inhibitor Ac-DEVD-CHO $(1 \mu \mathrm{M})$. All enzymatic reactions were performed at $37^{\circ} \mathrm{C}$ in two parallel samples in 96-well black microtiter plates (Corning, Acton, MA, USA) on the fluorometer SpectraFluor (Tecan, Grödig/ Salzburg, Austria) using the excitation filter of $405 \mathrm{~nm}$ and the emission filter of $510 \mathrm{~nm}$. The instrument was controled with the programme Biolise (Tecan). Fluorescence of the enzymatically released 4-amino-7-trifluoromethyl-coumarine (AFC) was measured in 30-sec intervals over a period of $60 \mathrm{~min}$. The measurements were standardised with a set of different AFC concentrations in the reaction buffer. The caspase-3-like activities were calculated from the steady-state region of progress curves [where the correlation between (AFC) and the reaction time gave $r>0.99$ ] and were expressed in $\mathrm{pkat} / \mathrm{mg}$ of total protein.

Statistical analysis. The statistical calculations were performed with the software SigmaStat (Systat Software, Point Richmond, CA, USA) and Stat200 (Biosoft, Cambridge, UK). A two-sided $\mathrm{P}<0.05$ was considered as a statistically significant difference. 

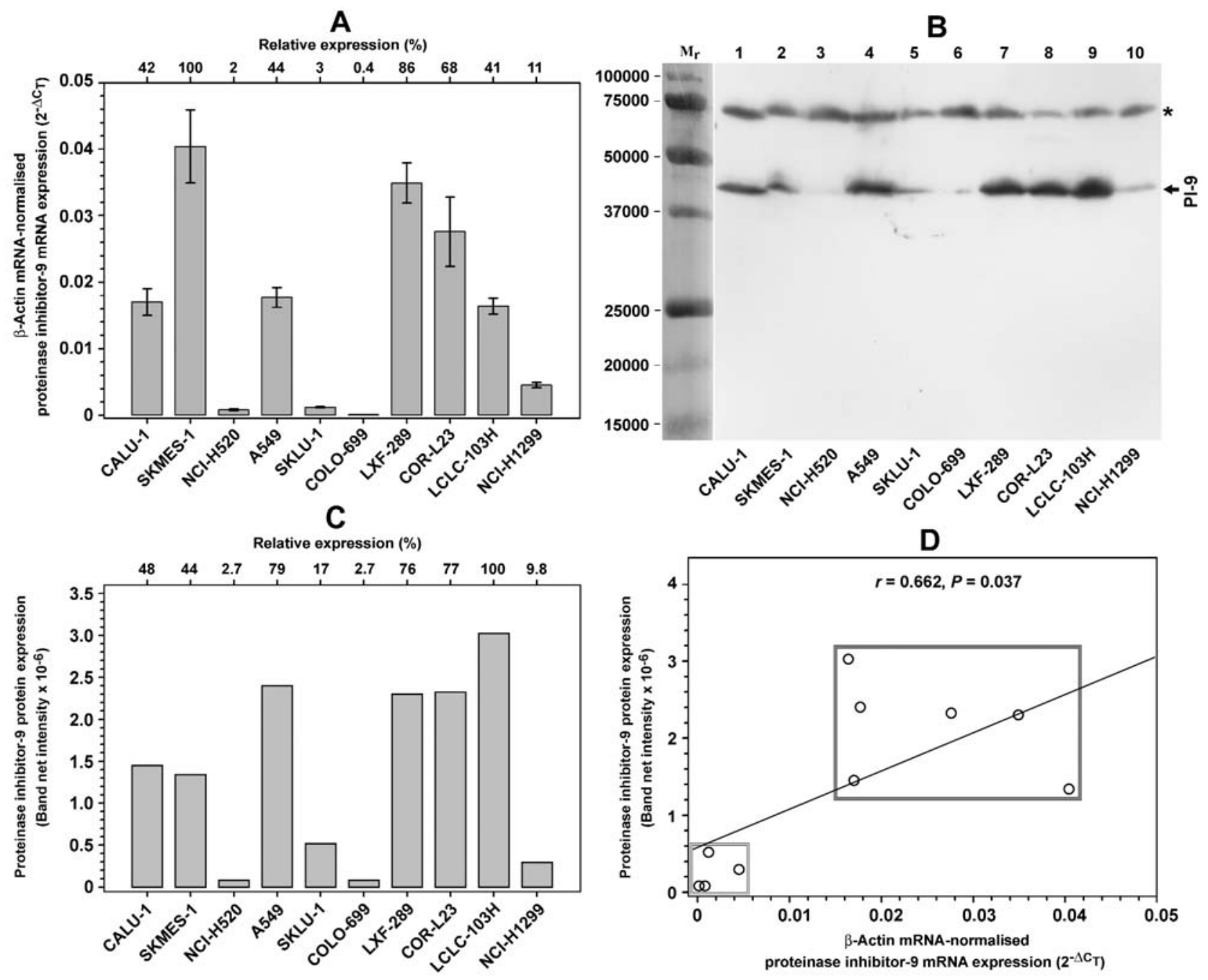

Figure 2. Analysis of PI-9 expression in non-small cell lung carcinoma cell lines. (A) Relative expression of PI-9 mRNA in the cell lines as quantitated by real-time RT-PCR. Data are indicated as mean \pm SEM from three independent experiments. (B) Expression of PI-9 protein $\left(\mathrm{M}_{\mathrm{r}} \sim 43000\right)$ in the cell lines as analysed by SDS-PAGE and immunoblotting. The asterisk denotes an unknown immunoreactive protein $\left(\mathrm{M}_{\mathrm{r}} \sim 71300\right)$. (C) Relative expression of PI-9 protein as determined by image analysis of the immunogram shown in (B). (D) Correlation analysis of mRNA and protein expression for PI-9, respectively, in the cell lines. The rectangles define two groups of NSCLC cell lines: the high and low PI-9 expressors. The Pearson linear correlation coefficient $r$ and its P-value are indicated.

\section{Results}

All NSCLC cell lines investigated in this study expressed PI-9 mRNA but the level of expression was highly variable (Figs. 1 and 2A). The expression of PI-9 mRNA was strong in six of ten examined NSCLC cell lines and it was weak in the remaining four (Fig. 2A). We also analysed the expression of PI-9 mRNA in SCLC cell lines which was lower, but not significantly, as compared to NSCLC cell lines $(\mathrm{P}=0.305$; Mann-Whitney test). The median/range values of the $\beta$-actin mRNA-normalized expression of PI-9 mRNA (2- $\left.{ }^{-\Delta \mathrm{C}_{\mathrm{T}}}\right)$ for NSCLC cell lines $(n=10)$ and SCLC cell line $(n=7)$ were: 0.0167/0.00008-0.0404 and 0.0037/0.0013-0.0118, respectively. Moreover, we could quantitate the expression of PI-9 mRNA in two SCLC tumours which was higher $\left(2^{-\Delta \mathrm{C}_{\mathrm{T}}}=0.0319\right.$ and 0.0140$)$ than in the examined SCLC cell lines.

The level of PI-9 protein, which was detected by Western blot analysis in the detergent-containing extracts or in cytosols from all studied NSCLC cell lines, was also highly variable (Figs. 2B and $\mathrm{C}$; and $3 \mathrm{~B}$ ). There was a significant positive correlation between the expression of PI-9 mRNA and protein in the investigated NSCLC cell lines (Fig. 2D). Among the studied NSCLC cell lines we distinguished high and low expressors of both PI-9 mRNA and protein (Fig. 2D). They showed significant difference in the expression of PI-9 transcript as well as PI-9 protein $(\mathrm{P}=0.0095$, Mann-Whitney test).

Since many serpins, including PI-9, are known to form SDS-stable covalent complexes with serine proteases including $\operatorname{GrB}(3,25,38,39)$, we attempted to detect formation of a complex between hrGrB and PI-9 protein present in the cytosol from NSCLC cell lines, using denaturing SDS-PAGE and immunoblotting. The incubation of cytosols from the cell lines with hrGrB resulted in a marked shift of the molecular mass of hrGrB to higher values (Fig. 3A) and a substantial decrease of the intensity of PI-9 protein band in parallel (Fig. 3B). Unfortunately, proving the molecular mass shift of 


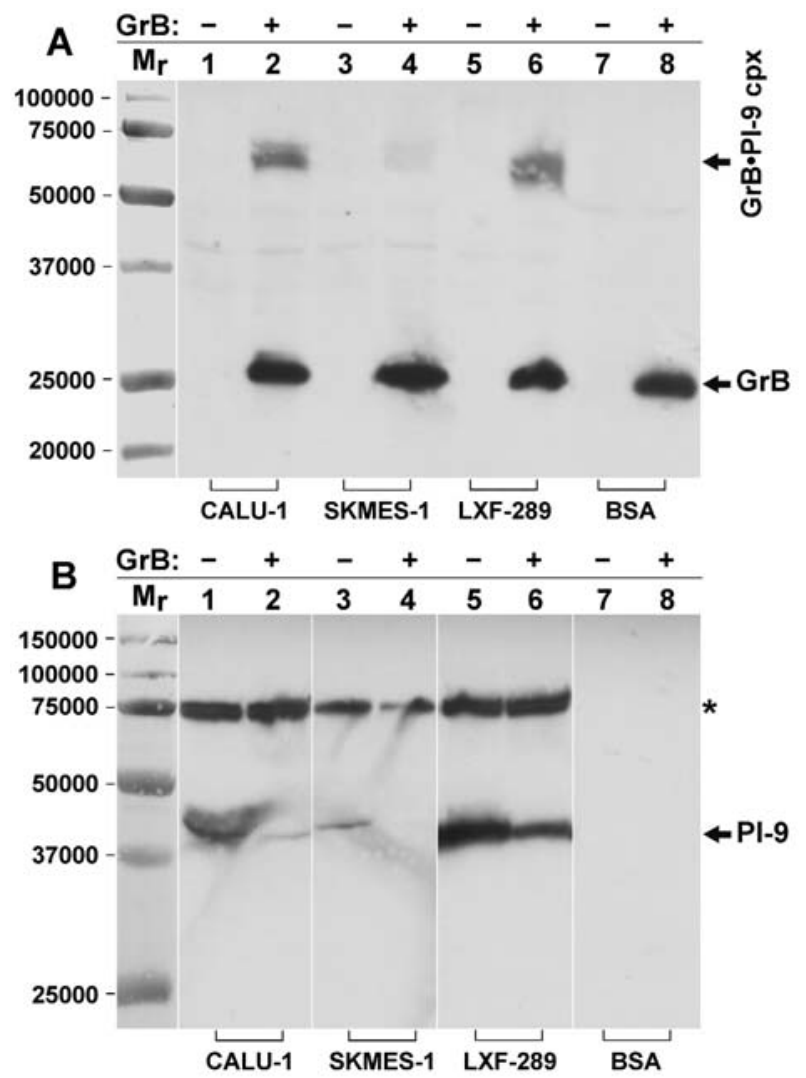

Figure 3. Interaction of human recombinant GrB with PI-9 in NSCLC cell cytosols. Cytosol samples from several NSCLC cell lines were incubated without (-) and with (+) human recombinant $\mathrm{GrB}$ and the reaction mixtures were analysed by denaturing SDS-PAGE and immunoblotting. As a negative control, a mixture of human recombinant $\mathrm{GrB}$ and bovine serum albumin (BSA) was used (lane 8 in A and B). (A) The membrane with transferred proteins was probed with an anti-GrB antibody (2C5). Arrows indicate an SDS-resistant GrB・PI-9 complex (cpx) and free GrB. (B) The membrane with transferred proteins was probed with an anti-PI-9 antibody (PI9-17). The asterisk denotes an unknown immunoreactive protein.
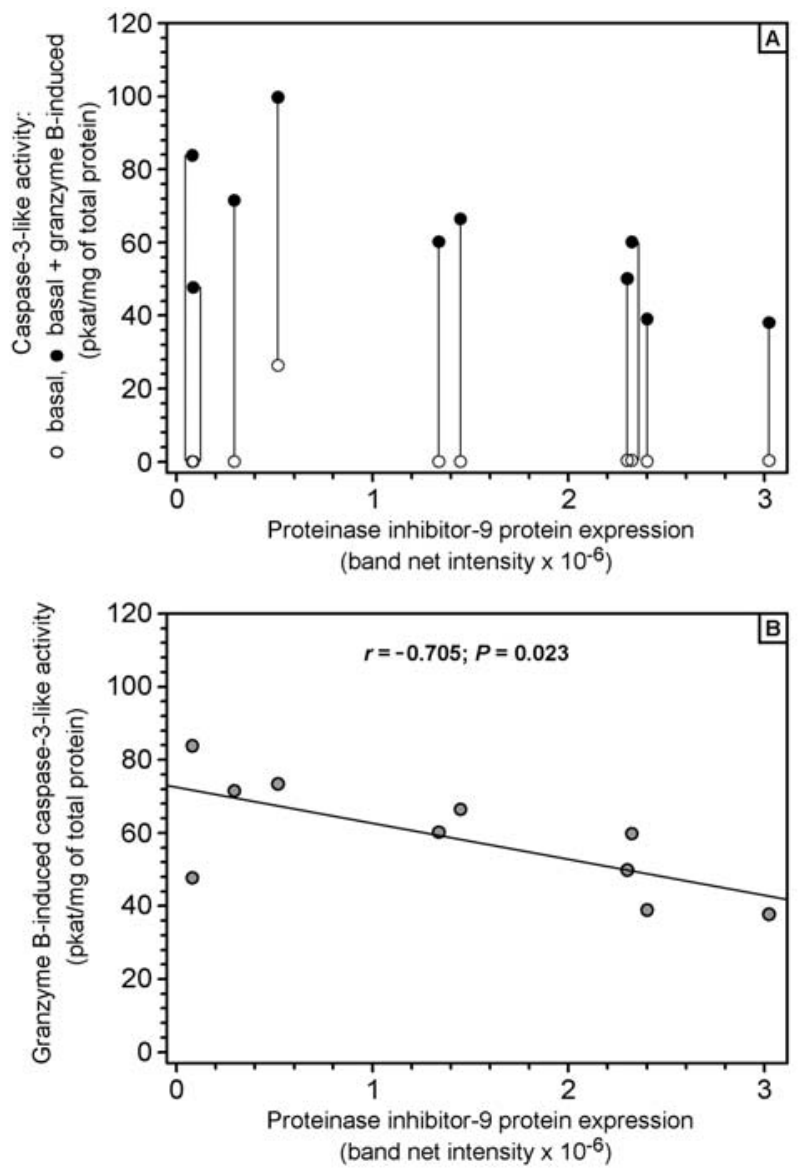

Figure 4. Relationship between the expression of PI-9 protein and the granzyme B-induced caspase-3-like activity in extracts from NSCLC cell lines. (A) Basal and total induced (i.e. basal + granzyme B-induced) caspase-3-like activity. (B) Correlation analysis of the granzyme B-induced caspase-3-like activity and the level of PI-9 protein expression in NSCLC cell lines. The Pearson linear correlation coefficient $\mathrm{r}$ and its P-value are indicated.

Table III. Impact of gender, smoking, tumour grade, and tumour stage on proteinase inhibitor-9 mRNA expression in non-small cell lung carcinomas.

\begin{tabular}{|c|c|c|c|}
\hline Category & $\mathrm{N}^{\mathrm{a}}$ & $\begin{array}{l}\text { ß-actin mRNA-normalised } \\
\text { expression of PI-9 mRNA }\left(2-{ }^{-C_{\mathrm{T}}}\right)^{\mathrm{b}}\end{array}$ & $\begin{array}{c}\text { Statistical } \\
\text { difference }(\mathrm{P})^{c}\end{array}$ \\
\hline \multicolumn{4}{|l|}{ Gender } \\
\hline Men & 110 & $0.0163(0.0002-0.2365)$ & \multirow[t]{2}{*}{0.162} \\
\hline Women & 40 & $0.0237(0.0008-0.3737)$ & \\
\hline \multicolumn{4}{|l|}{ Smoking } \\
\hline Non-smokers & 20 & $0.0155(0.0002-0.1486)$ & \multirow[t]{2}{*}{0.746} \\
\hline Smokers & 130 & $0.0178(0.0005-0.3737)$ & \\
\hline \multicolumn{4}{|l|}{ Tumor grade } \\
\hline Grade $1+2$ & 57 & $0.0131(0.0007-0.2132)$ & \multirow[t]{2}{*}{0.023} \\
\hline Grade 3 & 67 & $0.0240(0.0002-0.3737)$ & \\
\hline \multicolumn{4}{|l|}{ Tumor stage } \\
\hline Stage I & 83 & $0.0163(0.0002-0.2365)$ & \multirow[t]{2}{*}{0.125} \\
\hline Stage II+III & 63 & $0.0192(0.0008-0.3737)$ & \\
\hline
\end{tabular}

${ }^{a}$ The number, N, of examined NSCLC tissues belonging to the particular category is indicated. ${ }^{b}$ Data are indicated as median with the range in parentheses. 'Statistical difference was calculated by the Mann-Whitney test. 


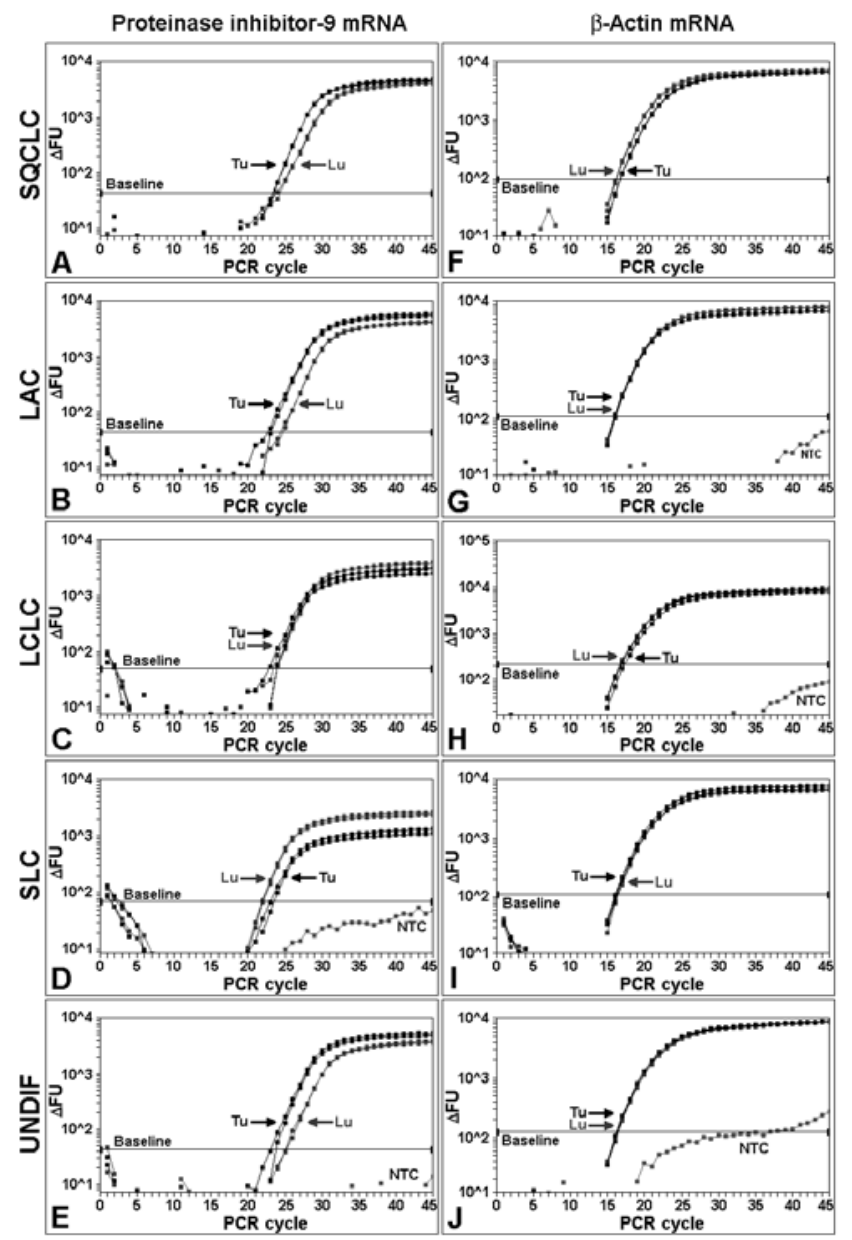

Figure 5. Real-time RT-PCR quantitation of expression of PI-9 and B-actin mRNAs in non-small cell lung carcinoma and matched lung tissues. The set of PCR amplification plots, representing the coupled real-time RT-PCR assays with an input of $200 \mathrm{ng}$ of total RNA and running in duplicate, shows the expression of PI-9 (A-E) and B-actin (F-J) mRNAs in five tumour (Tu) lung (Lu) matched pairs. The tumours were: squamous cell lung carcinoma (SQCLC), lung adenocarcinoma (LAC), large cell lung carcinoma (LCLC), sarcomatoid lung carcinoma (SLC), and undifferentiated lung carcinoma (UNDIF). NTC, no template control. $\triangle \mathrm{FU}$, background-subtracted fluorescence intensity (in arbitrary units) of the released reporter dye (6-FAM or VIC).

PI-9 to higher values was defeated in our experiments by the presence of an unknown protein reacting with the anti-PI-9 antibody PI9-17 and having $\mathrm{M}_{\mathrm{r}}$ of $\sim 71300$ (Figs. 2B and 3B). A similar unknown protein was observed earlier in melanomas (32).

There is evidence that GrB cleaves and activates procaspase-3 in NSCLC cells and tissues (40). To assess whether the expression of PI-9 protein in NSCLC cells may affect the GrB-mediated procaspase-3 activation, we investigated the relationship between the PI-9 protein and the GrB-induced caspase-3-like activity levels. Our results showed that the PI-9 expression level negatively correlates with the GrB-induced caspase-3-like activity in NSCLC cell extracts (Fig. 4). This evidence supports the hypothesis that the overexpression of PI-9 can contribute to the resistance of NSCLC cells against the GrB-mediated apoptosis.

In order to reveal the relationship between PI-9 expression in NSCLC tumours and the clinicopathological data of
NSCLC patients, we studied the expression status of PI-9 mRNA in the tumours and matched lungs from surgically treated patients. All examined NSCLC tumour types and lung tissues showed expression of PI-9 mRNA (Fig. 5). There was no statistically significant difference in the PI-9 mRNA expression between the tumours and lungs (Table II). However, in $26(17 \%)$ of 150 studied NSCLC patients the tumours had more than two-fold higher level of PI-9 mRNA as compared to matched lungs. The expression of PI-9 mRNA in NSCLC tissues (Table II) and NSCLC cells (see the data above) was not significantly different $(\mathrm{P}=0.222$; Mann-Whitney test). Furthermore, NSCLC tumours of various histopathological types showed comparable levels of PI-9 mRNA (Table II). Patients gender, smoking status and tumour stage did not significantly affect the expression of PI-9 mRNA (Table III). In contrast, PI-9 mRNA expression was significantly higher in the less-differentiated tumours (grade 3 ) as compared to the well-differentiated ones (grade 1+2) (Table III). Nevertheless, when SQCLCs and LACs were considered separately, the expression of PI-9 mRNA remained significantly higher in the less-differentiated LACs, but not in the less-differentiated SQCLCs $(\mathrm{P}=0.002$ and $\mathrm{P}=0.591$, respectively; Mann-Whitney test).

\section{Discussion}

In the present study, we demonstrated that both PI-9 mRNA and protein are expressed in NSCLC cells. Moreover, we revealed that PI-9 mRNA is expressed in SCLC cells at levels which were lower, but not significantly, as compared to NSCLC cells. There was a positive correlation between the levels of PI-9 mRNA and protein in NSCLC cells and, according to the differential abundance of PI-9 mRNA and protein expression, the cells could be classified as low and high PI-9 expressors. Differential expression of PI-9 mRNA in cancer cells was already reported for breast, cervical, oesophageal, gastric, colon, and nasopharyngeal carcinomas, and for melanomas and Ewing sarcomas (29,30,32,41-43). The mechanisms responsible in vivo for the differential expression of PI-9 in malignant tumours of the same type are not known so far. There is evidence that they may involve transcriptional upregulation of SERPINB9 gene expression, mediated by nuclear factor- $\mathrm{B}$ (44), the activated estrogen receptor- $\alpha(31,45)$ and/or the activator protein-1 (AP-1) transcription factors (44). Nevertheless, we detected only a weak or no increase of PI-9 mRNA expression in the interleukin-1ß- or estradiol-17ß-treated NSCLC cell lines (Rousalova et al, unpublished data). Since c-Jun and c-Fos, the major constituents of AP-1 transcription complex, seem to play an important role in tumorigenesis of NSCLCs (46-48), it is possible that the AP-1 transcription complex could be involved in the regulation of transcriptional expression of SERPINB9 gene in NSCLC cells.

In order to reveal whether PI-9 in the cytosol from NSCLC cells can interact with GrB, we incubated hrGrB with cytosols from several NSCLC cell lines and searched for molecular mass shift of hrGrB and PI-9 using denaturing SDS-PAGE and immunoblotting. We found a marked shift of hrGrB to higher $\mathrm{M}_{\mathrm{r}}$-values and a concurrent decrease of PI-9 protein band intensity. The $\mathrm{M}_{\mathrm{r}}$-shift of PI-9 protein, resulting 
from a covalent interaction of PI-9 with hrGrB, could not be reliably detected in our experiments due to the presence of an unknown immunoreactive protein which migrated to the same $\mathrm{M}_{\mathrm{r}}$-region as the hrGrB・PI-9 complex. Previously, the anti-PI-9 antibody PI9-17 was used for immunohistochemical detection of PI-9 protein expression in situ in normal and tumour cells $(20,30,32)$. Since this antibody is not completely specific for PI-9 protein, the immunohistochemical data obtained with it should be interpreted with caution.

We observed significant negative correlation between the level of PI-9 protein expression and the GrB-induced caspase3-like activity in extracts from NSCLC cell lines. This indicates that the overexpression of PI- 9 can contribute to the resistance of NSCLC cells against the GrB-mediated apoptosis. Thus, the PI-9-dependent inactivation of GrB blocks the GrB-catalysed cleavage of many intracellular substrates including procaspase-3 and -7, Bid, DNA fragmentation factor subunit A, and certain growth- and survival-promoting receptors $(16,17,40,49)$. There is evidence that PI-9 protein can be proteolytically inactivated by granzyme M (GrM) (50). Therefore, during the apoptotic attack of CTLs on the PI-9 expressing tumour cell targets, GrM internalised into the cytosol might attenuate the inhibitory effect of PI-9 on the delivered GrB.

Although the expression of PI-9 mRNA in NSCLC tumours and lungs was not significantly different, and patients gender and smoking status and tumour stage did not significantly affect the expression of PI-9 mRNA in the tumours, the less-differentiated LACs showed significantly higher expression of PI-9 mRNA as compared to the welldifferentiated tumours. Thus, it is tempting to speculate that poorly differentiated NSCLC tumours with upregulated PI-9 expression might be more resistant to the GrB-dependent immune deletion. To overcome such immunoresistance, the tumour cell-specific overloading of GrB would be required. Taking advantage of BIRC5 gene overexpression in lung cancer cells (51), the tumour cell-specific overexpression of GrB can be achieved via targeted delivery of recombinant DNA constructs consisting of a fusion of the BIRC5 promoter to the coding sequence of active GrB (52).

In conclusion, the results of the present study provide evidence that NSCLC cells express both PI-9 mRNA and protein and that there is a subset of NSCLC cells with upregulated PI-9 mRNA and protein expression. Moreover, our work revealed that the PI-9 protein expressed in NSCLC cells can inhibit the active GrB. Finally, analysis of PI-9 mRNA expression in NSCLC tumours from surgically treated patients showed that the expression of this transcript is upregulated in the less-differentiated LACs.

\section{Acknowledgements}

This work was supported by an institutional research project (MZO 00064211) from the Ministry of Health, Czech Republic.

\section{References}

1. Molina JR, Yang P, Cassivi SD, Schild SE and Adjei AA: Nonsmall cell lung cancer: epidemiology, risk factors, treatment, and survivorship. Mayo Clin Proc 83: 584-594, 2008.
2. Sprecher CA, Morgenstern KA, Mathewes S, Dahlen JR, Schrader SK, Foster DC and Kisiel W: Molecular cloning, expression, and partial characterization of two novel members of the ovalbumin family of serine proteinase inhibitors. J Biol Chem 270: 29854-29861, 1995.

3. Sun J, Bird CH, Sutton V, et al: A cytosolic granzyme B inhibitor related to the viral apoptotic regulator cytokine response modifier A is present in cytotoxic lymphocytes. J Biol Chem 271: 27802-27809, 1996.

4. Bird CH, Blink EJ, Hirst CE, et al: Nucleocytoplasmic distribution of the ovalbumin serpin PI-9 requires a nonconventional nuclear import pathway and the export factor Crm1. Mol Cell Biol 21: 5396-5407, 2001.

5. Cunningham TD, Jiang $X$ and Shapiro DJ: Expression of high levels of human proteinase inhibitor 9 blocks both perforin/ granzyme and Fas/Fas ligand-mediated cytotoxicity. Cell Immunol 245: 32-41, 2007.

6. Kummer JA, Micheau O, Schneider P, et al: Ectopic expression of the serine protease inhibitor PI9 modulates death receptormediated apoptosis. Cell Death Differ 14: 1486-1496, 2007.

7. Luo X, Budihardjo I, Zou H, Slaughter C and Wang X: Bid, a $\mathrm{Bcl} 2$ interacting protein, mediates cytochrome $\mathrm{c}$ release from mitochondria in response to activation of cell surface death receptors. Cell 94: 481-490, 1998.

8. Stennicke HR, Jurgensmeier JM, Shin H, et al: Pro-caspase- 3 is a major physiologic target of caspase-8. J Biol Chem 273: 27084-27090, 1998.

9. Metkar SS, Wang B, Ebbs ML, Kim JH, Lee YJ, Raja SM and Froelich CJ: Granzyme B activates procaspase-3 which signals a mitochondrial amplification loop for maximal apoptosis. J Cell Biol 160: 875-885, 2003.

10. Han J, Goldstein LA, Gastman BR, Froelich CJ, Yin XM and Rabinowich H: Degradation of Mcl-1 by granzyme B: implications for Bim-mediated mitochondrial apoptotic events. J Biol Chem 279: 22020-22029, 2004.

11. Han J, Goldstein LA, Gastman BR, Rabinovitz A and Rabinowich H: Disruption of Mcl-1.Bim complex in granzyme B-mediated mitochondrial apoptosis. J Biol Chem 280: 16383-16392, 2005.

12. Herrant M, Jacquel A, Marchetti S, Belhacene N, Colosetti P, Luciano $\mathrm{F}$ and Auberger P: Cleavage of Mcl-1 by caspases impaired its ability to counteract Bim-induced apoptosis. Oncogene 23: 7863-7873, 2004.

13. Adrain C, Murphy BM and Martin SJ: Molecular ordering of the caspase activation cascade initiated by the cytotoxic $\mathrm{T}$ lymphocyte/natural killer (CTL/NK) protease granzyme B. J Biol Chem 280: 4663-4673, 2005.

14. Milhas D, Cuvillier O, Therville N, et al: Caspase-10 triggers Bid cleavage and caspase cascade activation in FasL-induced apoptosis. J Biol Chem 280: 19836-19842, 2005.

15. Yin XM: Bid, a BH3-only multi-functional molecule, is at the cross road of life and death. Gene 369: 7-19, 2006

16. Casciola-Rosen L, Garcia-Calvo M, Bull HG, Becker JW, Hines T, Thornberry NA and Rosen A: Mouse and human granzyme $\mathrm{B}$ have distinct tetrapeptide specificities and abilities to recruit the Bid pathway. J Biol Chem 282: 4545-4552, 2007.

17. Cullen SP, Adrain C, Luthi AU, Duriez PJ and Martin SJ: Human and murine granzyme B exhibit divergent substrate preferences. J Cell Biol 176: 435-444, 2007.

18. Mahrus S and Craik CS: Selective chemical functional probes of granzymes A and B reveal granzyme B is a major effector of natural killer cell-mediated lysis of target cells. Chem Biol 12: 567-577, 2005.

19. Cullen SP and Martin SJ: Mechanisms of granule-dependent killing. Cell Death Differ 15: 251-262, 2008.

20. Bladergroen BA, Strik MC, Bovenschen N, et al: The granzyme $\mathrm{B}$ inhibitor, protease inhibitor 9 , is mainly expressed by dendritic cells and at immune-privileged sites. J Immunol 166: 3218-3225, 2001.

21. Hirst CE, Buzza MS, Bird CH, et al: The intracellular granzyme B inhibitor, proteinase inhibitor 9 , is up-regulated during accessory cell maturation and effector cell degranulation, and overexpression enhances CTL potency. J Immunol 170: 805-815, 2003.

22. Ida H, Nakashima T, Kedersha NL, et al: Granzyme B leakageinduced cell death: a new type of activation-induced natural killer cell death. Eur J Immunol 33: 3284-3292, 2003.

23. Classen CF, Bird PI and Debatin KM: Modulation of the granzyme B inhibitor proteinase inhibitor 9 (PI-9) by activation of lymphocytes and monocytes in vitro and by Epstein-Barr virus and bacterial infection. Clin Exp Immunol 143: 534-542, 2006. 
24. Bladergroen BA, Strik MC, Wolbink AM, Wouters D, Broekhuizen R, Kummer JA and Hack CE: The granzyme B inhibitor proteinase inhibitor 9 (PI9) is expressed by human mast cells. Eur J Immunol 35: 1175-1183, 2005.

25. Buzza MS, Hirst CE, Bird CH, Hosking P, McKendrick J and Bird PI: The granzyme B inhibitor, PI-9, is present in endothelial and mesothelial cells, suggesting that it protects bystander cells during immune responses. Cell Immunol 210: 21-29, 2001.

26. Young JL, Sukhova GK, Foster D, Kisiel W, Libby P and Schonbeck U: The serpin proteinase inhibitor 9 is an endogenous inhibitor of interleukin 1beta-converting enzyme (caspase-1) activity in human vascular smooth muscle cells. J Exp Med 191: 1535-1544, 2000.

27. Bots M, de Bruin E, Rademaker-Koot MT and Medema JP Proteinase inhibitor-9 expression is induced by maturation in dendritic cells via p38 MAP kinase. Hum Immunol 68: 959-964, 2007.

28. Buzza MS, Hosking P and Bird PI: The granzyme B inhibitor, PI-9, is differentially expressed during placental development and up-regulated in hydatidiform moles. Placenta 27: 62-69, 2006.

29. Medema JP, de Jong J, Peltenburg LT, et al: Blockade of the granzyme $\mathrm{B} /$ perforin pathway through overexpression of the serine protease inhibitor PI-9/SPI-6 constitutes a mechanism for immune escape by tumors. Proc Natl Acad Sci USA 98 11515-11520, 2001.

30. Oudejans JJ, Harijadi H, Kummer JA, et al: High numbers of granzyme $\mathrm{B} / \mathrm{CD} 8$-positive tumour-infiltrating lymphocytes in nasopharyngeal carcinoma biopsies predict rapid fatal outcome in patients treated with curative intent. J Pathol 198: 468-475, 2002.

31. Jiang X, Patterson NM, Ling Y, Xie J, Helferich WG and Shapiro DJ: Low concentrations of the soy phytoestrogen genistein induce proteinase inhibitor 9 and block killing of breast cancer cells by immune cells. Endocrinology 149: 5366-5373, 2008.

32. van Houdt IS, Oudejans JJ, van den Eertwegh AJ, et al: Expression of the apoptosis inhibitor protease inhibitor 9 predicts clinical outcome in vaccinated patients with stage III and IV melanoma. Clin Cancer Res 11: 6400-6407, 2005.

33. Travis WD, Brambilla E, Müller-Hermelink HK, Harris CC (eds): Pathology and Genetics of Tumours of the Lung, Pleura, Thymus and Heart. IARC Press, Lyon, 2004.

34. Mountain CF: Revisions in the International system for staging lung cancer. Chest 11: 1710-1717, 1997.

35. Livak KJ and Schmittgen TD: Analysis of relative gene expression data using real-time quantitative PCR and the $2^{-\Delta \Delta C}$ method. Methods 25: 402-408, 2001.

36. Smith PK, Krohn RI, Hermanson GT, et al: Measurement of protein using bicinchoninic acid. Anal Biochem 150: 76-85, 1985.

37. Schägger $\mathrm{H}$ and von Jagow G: Tricine-sodium dodecylsulfatepolyacrylamide gel electrophoresis for the separation of proteins in the range from 1 to $100 \mathrm{kDa}$. Anal Biochem 166: 368-379, 1987.
38. Law RH, Zhang Q, McGowan S, et al: An overview of the serpin superfamily. Genome Biol 7: 216, 2006.

39. Mangan MS, Kaiserman D and Bird PI: The role of serpins in vertebrate immunity. Tissue Antigens 72: 1-10, 2008.

40. Krepela E, Prochazka J, Liu X, Fiala P and Kinkor Z: Increased expression of Apaf- 1 and procaspase- 3 and the functionality of intrinsic apoptosis apparatus in non-small cell lung carcinoma. Biol Chem 385: 153-168, 2004.

41. Tanaka K, Harashima N, Niiya F, et al: Serine proteinase inhibitor 9 can be recognized by cytotoxic T lymphocytes of epithelial cancer patients. Jpn J Cancer Res 93: 198-208, 2002.

42. Majima T, Ichikura T, Chochi K, et al: Exploitation of interleukin- 18 by gastric cancers for their growth and evasion of host immunity. Int J Cancer 118: 388-395, 2006.

43. de Hooge AS, Berghuis D, Santos SJ, et al: Expression of cellular FLICE inhibitory protein, caspase- 8 , and protease inhibitor-9 in Ewing sarcoma and implications for susceptibility to cytotoxic pathways. Clin Cancer Res 13: 206-214, 2007.

44. Kannan-Thulasiraman P and Shapiro DJ: Modulators of inflammation use nuclear factor-kappa B and activator protein-1 sites to induce the caspase-1 and granzyme $\mathrm{B}$ inhibitor, proteinase inhibitor 9. J Biol Chem 277: 41230-41239, 2002.

45. Jiang X, Ellison SJ, Alarid ET and Shapiro DJ: Interplay between the levels of estrogen and estrogen receptor controls the level of the granzyme inhibitor, proteinase inhibitor 9 and susceptibility to immune surveillance by natural killer cells. Oncogene 26: 4106-4114, 2007

46. Wodrich W and Volm M: Overexpression of oncoproteins in non-small cell lung carcinomas of smokers. Carcinogenesis 14: 1121-1124, 1993.

47. Szabo E, Riffe ME, Steinberg SM, Birrer MJ and Linnoila RI: Altered cJUN expression: an early event in human lung carcinogenesis. Cancer Res 56: 305-315, 1996.

48. Shimizu Y, Kinoshita I, Kikuchi J, Yamazaki K, Nishimura M, Birrer MJ and Dosaka-Akita H: Growth inhibition of non-small cell lung cancer cells by AP-1 blockade using a cJun dominantnegative mutant. Br J Cancer 98: 915-922, 2008.

49. Loeb CR, Harris JL and Craik CS: Granzyme B proteolyzes receptors important to proliferation and survival, tipping the balance towards apoptosis. J Biol Chem 281: 28326-28335, 2006.

50. Mahrus S, Kisiel W and Craik CS: Granzyme M is a regulatory protease that inactivates proteinase inhibitor 9 , an endogenous inhibitor of granzyme B. J Biol Chem 279: 54275-54282, 2004

51. Falleni M, Pellegrini C, Marchetti A, et al: Survivin gene expression in early-stage non-small cell lung cancer. J Pathol 200: 620-626, 2003.

52. Caldas H, Jaynes FO, Boyer MW, Hammond S and Altura RA: Survivin and Granzyme B-induced apoptosis, a novel anticancer therapy. Mol Cancer Ther 5: 693-703, 2006. 